\title{
A REVIEW OF THE TAXONOMY AND MORPHOLOGY OF THE BEROTHIDAE, WITH THE DESCRIPTION OF A NEW SUBFAMILY FROM CHILE (NEUROPTERA)
}

\author{
By Ellis G. MacLeod ${ }^{1}$ and Phillip A. Adams ${ }^{2}$
}

\section{INTRODUCTION}

Collections of Neuroptera which we have received from Chile contain a series of specimens of an unusual berothid representing an undescribed subfamily. Study of these specimens has convinced us that, in addition to throwing new light on the probable evolutionary relationships within the Berothidae, the new form makes somewhat easier an understanding of some of the structural peculiarities of the more-specialized species of this family.

The description of the new subfamily has thus been combined with a reexamination of certain aspects of the morphology of berothids and a redefinition and generic synopsis of the subfamilies. These points will be considered in detail following the taxonomic description of the new form.

\section{Cyrenoberotha, new genus}

\section{Figures 9, I 4-I 7}

Description. Head capsule and mouthparts, particularly palpi, elongate (figs. I, 2, 3, 4) ; vertex moderately elevated, without raised tubercles; head not particularly inflated behind eyes; antenna moniliform, with short scape. Prothorax (fig. I) somewhat more elongate and less robust than usual in this family. Prosternum small, quadrangular. Legs slender, setose, without raptorial modifications. Abdomen short, ninth tergite distinct from ectoproct in both sexes; callus cerci of ectoprocts present, with trichobothrial setae.

Male (figs. 7, 8, 9): Ioth sternite not discernible beneath anus. Gonarcus arms disconnected medially, with 9 th gonocoxites $(=$ "parameres") ${ }^{3}$ articulated to ventral tips of arms, these latter

\footnotetext{
${ }^{1}$ Department of Entomology, University of Illinois, Urbana, Illinois.

${ }^{2}$ Department of Biological Sciences, California State College, Fullerton, California.

${ }^{3}$ The reasons for the adoption of the terminology utilized here for the internal male genitalia have been briefly outlined by Adams (1967). A short discussion of the modified terminology which we have applied to the female terminalia of berothids is given on p. 247 of the present paper.

Manuscript received by the editor August 5, 1967.
} 

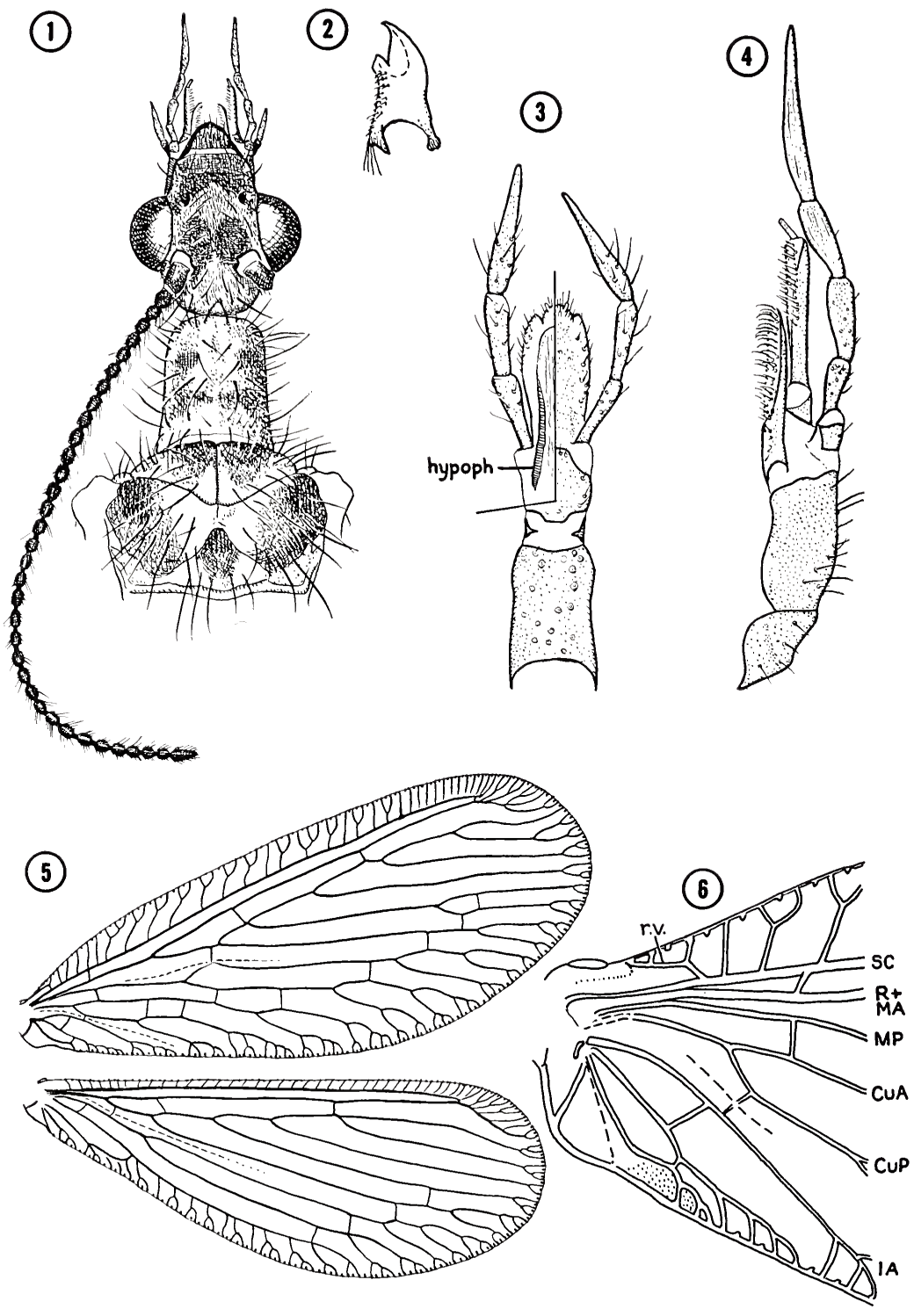

MacLeod and Adams - Berothidae 
expanded distally with prominent apical teeth; mediuncus ( $=$ "pseudopenis", "penisfilum”) detached from gonarcus, base laterally compressed forming an elongate sclerite and median apodeme in dorsal wall of ductus ejaculatorius, free distal portion rodlike, lacking setae at tip.

Female (figs. I4, I5, I6, I 7): 7 th sternite slightly desclerotized at posterior midline; 8th sternite (= "subgenital plate") divided into large, bilateral fragments which are somewhat posteriorly displaced beneath 9 th tergite; 8th gonocoxities (= "postgenitale") reflexed dorsally toward genital chamber (figs. I4, I5, I6, $8 \mathrm{gcx}$ ); 9th gonocoxites (= "gonapophyses laterales") fused to Ioth sternite apically; 9th gonapophyses represented by micro-imbricate lobes which when pressed against 8 th gonocoxites close genital chamber ventrally (figs. I 4, I 5, 9 gph); bursa copulatrix widely open to genital chamber medially, with bilateral pouches opening to medial portion through narrow slits (fig. I 4, cop. b.) ; spermatheca opening broadly from median roof of bursa (fig. I4, sp; fig. I7), continuing as a simple but intricately coiled tube and connecting via a short duct (fertilization canal) to common oviduct (figs. I 4, I 7, fert. c.) ; collaterial gland unbranched (fig. I 4, coll. gl.); gonopore opening through anterior surface of genital chamber, just behind posterior margin of 8th gonocoxites (fig. I 5, gpr.).

Wing tips (fig. 5) bluntly rounded. Forewing: small recurrent humeral vein present (fig. 6, r.v.). Sc distally either connected to $\mathrm{R}$ by a crossvein, or these veins sometimes fused at a point. $\mathrm{R}$ fewbranched, with two radial crossveins; $M$ separate from $R$ to base, diverging at level of humeral vein. $\mathrm{MP}$ and $\mathrm{Cu}$ dichotomously branched (except at margin). One series (the outer) of gradate veins. Hindwing: recurrent humeral vein absent, discal area almost devoid of crossveins, except for a few outer gradates. Basal piece of MA (= " $r-m$ crossvein") straight, vertical. CuA parallels wing

Explanation of Plate 31

Figs. 1-4 based on paratypes, Figs. 5-6 on ô holotype. Cyrenoberotha penai n. sp.: Fig. 1. Habitus of head, pro- and mesothorax, head rotated anteriad. Fig. 2. Mandible, anterior aspect. Fig. 3. Labium-posterior surface on right, insert on left showing anterior surface and hypopharynx. Fig. 4. Anterior surface of right maxilla. Fig. 5. Right wings. Fig. 6. Detail of base of right forewing.

Abbreviations: $1 \mathrm{~A}$ - first anal vein; $\mathrm{CuA}, \mathrm{CuP}-$ anterior and posterior branches of cubital vein; hypoph - hypopharynx; MP - posterior branch of median vein; $\mathrm{R}+\mathrm{MA}$ - fused base of radial and anterior median veins; r.v. - recurrent humeral vein; Sc-subcostal vein. 
margin for a long distance, with I2-I 5 pectinate branches; no trace of $\mathrm{CuP}$ visible; cu-I a crossvein moderately long, sinuous.

This genus differs from all known berothids in the absence of any trace of fusion of the 9th tergite and ectoprocts, the possession of a recurrent humeral vein in only the forewing, and in the ventrally extended head capsule and correlated attenuate mouthparts.

We take pleasure in naming the type species after its collector, the prominent Chilean naturalist, Luis E. Peña.

\section{Cyrenoberotha penai new species}

Head: anterior tentorial pits prominent; labrum about $2 / 3$ as long as broad, rest of head brown; face and vertex with white setae, those on vertex curved forward. Antennae: fossae widely separated, located high on face; scape short, pedicel as long as 2 flagellar segments, flagellum dark; flagellar segments 35 in male, 3I-34 in female, shorter in female than in male; setae white, not in definite whorls.

Pronotum longer than wide (mean total length, $\sigma^{\pi}-0.48$, 우 0.60 ; midline length, $\sigma^{\top}-0.40$, $9-0.43$; width, $\sigma^{\top}-0.40$, 우 $0.48 \mathrm{~mm}$ ) ; not especially robust, brown with paler anterior median stripe; with erect white setae (fig. I).

Prescuta pale posteriorly; scuta pale in middle third; scutella pale along anterolateral margins (fig. I). Anterior cervical sclerite straight, stiff, slender; I.8 times as long as posterior cervical in male; 2.5 times as long in female. Pleurae brown.

Legs slender, tibiae pale at middle; tarsi pale basally. Leg setae mostly pale, inclined at about $45^{\circ}$, length at most about twice leg diameter. No tibial spurs. The 4 basal tarsomeres each with a pair of stout setae, on apicolateral corners of plantar surface. Claws slender, strongly curved, without teeth; arolium small.

Wings: membrane transparent, without markings; veins uniformly brown-fuscous. Forewing - costal area slightly broadened at base ; middle costal veinlets with 2 or 3 branches; apical veinlets not forked; $\mathrm{R}$ dips posteriorly at apex; Rs 4-5 branched; MA forks near margin; 4-5 outer gradates. A thyridium at intersection of ma-mp crossvein with MPI. Hindwing - costal area narrow; 2-4 outer gradates.

Setae on dorsal surface of forewing erect, dark; near wing base, about twice as long as average distance between veins; shorter apically; on ventral surface and both surfaces of hindwing, setae shorter, directed basally at about $75^{\circ}$ to long axis of vein. Posterior margin of both wings basally fringed with long, straight, white setae.

Abdomen: brown, unmarked; setae mostly pale, those on membranous areas with prominent dark bases. Male (figs. 7, 8, 9) : apex 
enlarged. Ninth sternite produced, apex bluntly pointed, with tuft of vertical white setae; a prominent marginal tooth each side. Ninth tergite extends farther ventrad than lateral margins of 8th sternite, forming articulation with 9th sternite. Ectoprocts produced, clasperlike; callus cerci pale. Lobes between the gonarcus arms with oval, well-separated scales; between gonocoxites and a median area ventral to mediuncus with larger, imbricate scales; gonocoxites with prominent tooth on expanded apical portion; free portion of mediuncus (fig. 8, mu) bent dorsally, recurved distally. Female (figs. I 4, I 5, I6) : ectoprocts short; eighth gonocoxites little sclerotized, anterior margin deflexed, incised medially. Accessory gland reservoir bulbous, duct connecting reservoir to genital chamber lined with microtrichia. Spermathecal duct from bursa copulatrix dilated, large, more weakly sclerotized than remainder of spermatheca. Spermathecal coiling pattern as in fig. I 7 .

Measurements ( $\mathrm{mm}$, range, means in parenthesis), $\mathrm{n}=80^{\circ},=$

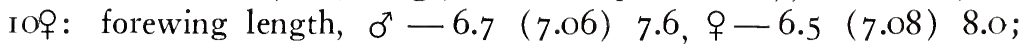
body length, $\sigma^{7}-4.7$ (5.2) 5.5 , + - 4.3 (5.I) 5.7 ; antenna length, $\sigma^{x}-3.5$ (3.7) 4.1 , $9-2.7$ (3.0) 3.1 ; tenth flagellar segment (two of each sex measured), $0^{\pi}$ - length 0.11 , width 0.06 , + - length 0.08 , width 0.06 .

Leg segments of a $\sigma^{7}$ with a $7.6 \mathrm{~mm}$ forewing: coxae $.74 / .55 / .48$; femora I.02/.98/1.15; tibiae I.0/I.I 7/1.92; tarsi .83 (.28-.16$.12-.09-.16) / .65 / .78$.

Sexual dimorphism, common in some berothids, is limited to the larger eyes, proportionately narrower face, longer antennae with more, elongate segments, and shorter cervical sclerites in the male. No squamae or other setal modifications are present in either sex.

Holotype, a pinned $\sigma^{x}$ : Coquimbana, North of Huasco River, Atacama, Chile; X-20-1957; L. E. Peña, collector (Museum of Comparative Zoology, Harvard University - type \# 31568). Paratypes (all coll. by L. E. Peña) - Atacama, Coquimbana, N. of Huasco R.; X-20-57: Iㅇ. Quebrada Algodon, near Carrizal Bajo; X-18-1957：80 , 569. X-20-1957： I․ Coquimbo, Tofo; X-271957: 2ㅇ. (U. S. National Museum, British Museum (N. H.), Adams Coll., MacLeod Coll., Tjeder Coll.).

The gut contents of two specimens consist of pollen grains of Salix (identified by D. L. Walkington).

Discussion. Perhaps the sclerites which we have identified in the female as separated fragments of the 8th sternite could be equally as well regarded as derivatives of the 9th tergite, but since an 8 th 

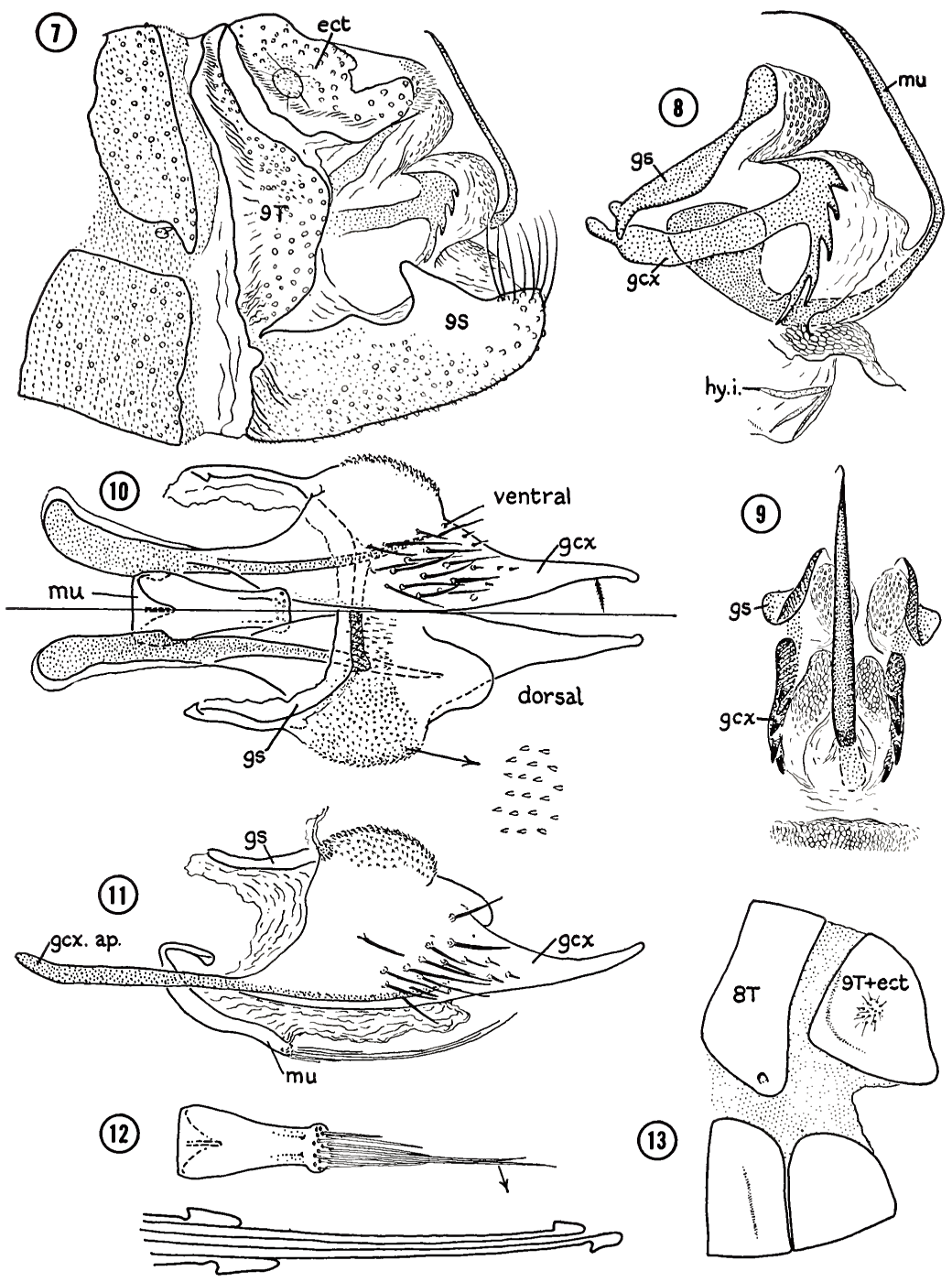

MacLeOd AND AdAMS - Berothidae 
sternite, in some cases very large (cf Nosybus), is present in nearly all berothids and is usually bilobed it seems unlikely that such an alternative interpretation is correct.

The only other Berothidae described from southern South America are Naizema patagonica Navás and Espetera mendozina (EsbenPetersen). Neither of these has been adequately known and because of the presence of recurrent humeral veins in the wings of $N$. patagonica, doubt has been expressed that this species is even a berothid (Carpenter, 1940; Tjeder, 1959). While it has not been possible to examine Navás' type of $N$. patagonica, male and female cotypes of E. mendozina have been loaned to us for study. Examination of these specimens and of Navás' descriptions of $N$. patagonica ( I919, 1929) has convinced us that Esben-Petersen's species is certainly congeneric with $N$. patagonica and, indeed, is very likely the same species. Although it shows no close similarity to Cyrenoberotha, a redescription and catalogue of Naizema will be presented here as the rather unusual structures of this group provide insight into some of the structural specializations of the Berothinae.

\section{Naizema Navás \\ Figures 20-25}

Naizema Navás, 1919, Rev. R. Acad. Cienc. Madrid 17: 298-299.

Type species (by original designation): Naizema patagonica Navás. Navás, 1929, Mem. Acad. Cienc. Zaragoza 2: 19-20. Handschin, 1935,

Rev. Suisse Zool. 42: 700. Carpenter, 1940, Proc. Amer. Acad. Arts

\section{Explanation of Plate 32}

Cyrenoberotha penai n. sp.: Figs. 7-9 of $\hat{o}$ holotype. Lomamyia squamosa Carpenter, ô: Figs. 10-13, drawn from a specimen from $3 \mathrm{mi}$. NW of La Palmilla on Highway Sur No. 19, B. Calif., Mexico; 18-1-59; H. B. Leech Col.; in the collection of the California Academy of Sciences. This specimen is the same as that studied and figured by Acker (1960), where it is identified as "Lomamyia sp."

Fig. 7. Lateral aspect of terminalia. Fig. 8. Detail of gonarcus, gonocoxites, mediuncus and hypandrium internum, drawn after the removal of these structures from the abdomen, lateral aspect. Fig. 9. Same as Fig. 8, posterior aspect. Fig. 10. Divided dorsal and ventral views of fused gonarcus and gonocoxites and of mediuncus (terminal tuft of setae of mediuncus omitted), inset showing detail of microtrichia on surface of gonarcus. Fig. 11. Same, lateral view. Fig. 12. Ventral view of mediuncus, inset showing detail of tips of two longest (median) pairs of setae. Fig. 13. Lateral view of terminal abdominal segments of abdomen.

Abbreviations: ect-ectoproct; gcx - gonocoxite; gcx. ap. - basal apodeme of gonocoxite; gs - gonarcus; hy. i. - hypandrium internum; mu mediuncus; $9 \mathrm{~S}-9$ th sternite; $8 \mathrm{~T}, 9 \mathrm{~T}-8$ th, 9 th tergites; $9 \mathrm{~T}+$ ect - fused 9 th tergite and ectoproct. 
Sci. 74: 256. Tjeder, 1959, South African Animal Life 6: 260.

Espetera Navás, 1929, Mem. Acad. Cienc. Zaragoza 2: 29.

Type species (by original designation): Berotha mendozina Esben-

Petersen. Tjeder, 1959, South African Animal Life 6: 293. NEW SYNONYMY.

Description. Face short, hardly extending ventrad of eyes; anterior vertex tubercle transverse, confluent with well-demarked lateral tubercles; vertex and area behind eyes inflated. Scape length equals about 4/5 eye diameter; flagellum stout, segments short, wide. Mouthparts sunken into ventral concavity of head, mandibles nearly vestigial, maxillae and labium greatly reduced. Pronotum transverse, arched, lightly sclerotized, two transverse furrows. Trichobothrial setae present at apex of abdomen but callus cerci poorly delimited.

Male (figs. 2O, 2I, 22) : ninth tergite and ectoprocts fused, ninth sternite a narrow band, tenth sternite absent. Gonarcus desclerotized medially, articulated laterally to apodemes of ninth tergite. Gonocoxites articulated to gonarcus arms laterally; space between gonarcus and gonocoxites weakly desclerotized dorsally. Rectangular median sclerite extending from gonarcus to mediuncus pouch. Mediuncus withdrawn and coiled in deep pouch, bearing lateral arms and long terminal setae.

Female (figs. 23, 24): 7th sternite large, desclerotized posteromedially and weakened along ventral midline. Eighth sternite bandlike. Ninth tergite discernible but fused with ectoprocts. Ninth gonocoxites with hypocaudae represented by short tubercles. Ninth gonapophyses developed as short projections from posteromedial surfaces of ninth gonocoxites, inserted into transverse, cup-like eighth gonocoxites to close genital chamber. Copulatory bursa large, membranous, widely confluent with genital chamber. Spermathecal duct short, membranous. Spermatheca with a thin-walled, saccate, expansible posterior diverticulum and a short, tubular anterior extension which is convoluted and weakly sclerotized.

Forewing (fig. 25): elongate, apical and posterior edges straight (ㅇ) or concave $\left(\sigma^{x}\right)$. Recurrent humeral vein present; Sc apically connected to $R$ by a crossvein; base of $M$ distinct from $R$, fusing for a distance beginning at level of recurrent humeral vein. Inner gradate series well-developed; outer series sometimes absent. Hindwing: Sc connected to $\mathrm{R}$ by a crossvein; recurrent humeral vein present; $M A$ branches from the stem of $M$ and fuses with $R$ basad of level of recurrent vein (difficult to see, because of the proximity of M and R, basally); stem of MP not fused with R basally. Vestige 
of distal portion of $\mathrm{CuP}$ extending basad from cu-a crossvein. Single gradate series; 3-4 crossveins. No squamae on wings or body.

Discussion. This genus is quite similar to Trichoberotha Handschin in the structure of the head capsule and prothorax, in the presence of recurrent humeral veins in both pairs of wings, in the general plan of venation, and in the small band-like shape of the eighth sternite of the female. Trichoberotha has larger mandibles, no trace of fusion of the bases of $M$ and $R$ in the forewing, and shows several important differences in the structure of the male and female genitalia.

Naizema mendozina (Esben-Petersen), n. comb.

Berotha mendozina Esben-Petersen, 1912, Entomol. Mitteilungen $1: 271$, fig. 5 (male terminalia). Described from three cotypes now in the Universitetets Zoologiske Museum, Copenhagen. We designate as lectotype a pinned male of this series bearing the following labels: "Mendoza 1904-05 A.C.J.H."; "Coll. Esben-Petersen"; "Type"; and "Berotha mendozina n. sp., Type!". The cleared abdomen is in glycerine in a glass microvial on the pin with the specimen.

Espetera mendozina Navás, 1929, Mem. Acad. Cienc. Zaragoza 2: 30-31, figs. 10 (male terminalia), 11 (photograph of wings).

Distribution. Argentina: Mendoza-Santa Rosa, Potrerillos.

\section{Naizema patagonica Navás}

Naizema patagonica Navás, 1919, Rev. R. Acad. Cienc. Madrid 17: 299-300, fig. 5 (drawing of wing bases). Type, stated to be in Navás Coll., not examined. Navás, 1929, Mem. Acad. Cienc. Zaragoza 2: 20-22, fig. 7 (drawing of wing bases), fig. 8 (drawing of forewing).

Distribution. Argentina: Patagonia.

Notes on THE MORPHOLOGY OF THE

TERMINAL ABDOMINAL SEGMENTS OF BEROTHIDAE

Several inconsistencies and errors have entered the literature on berothid genital morphology since most previous studies have dealt with rather specialized forms. In the male, Carpenter ( 1940 ) interpreted the reduced sclerite of the fused gonarcus and gonocoxites of Lomamyia as representing the apparently missing "IOth tergites" (ectoprocts), while Tjeder ( I959) did not realize that both gonarcus and gonocoxites (parameres in his terminology) are represented in the seemingly single sclerite of Acroberotha xiphophora Tjeder. The generalized arrangement of these sclerites shown by Cyrenoberotha (as well as by Nosybus and Naizema) indicates that in the specialized, higher berothids the gonocoxites have become much reduced with the weakly sclerotized space between them and the gonarcus becom- 
(14)
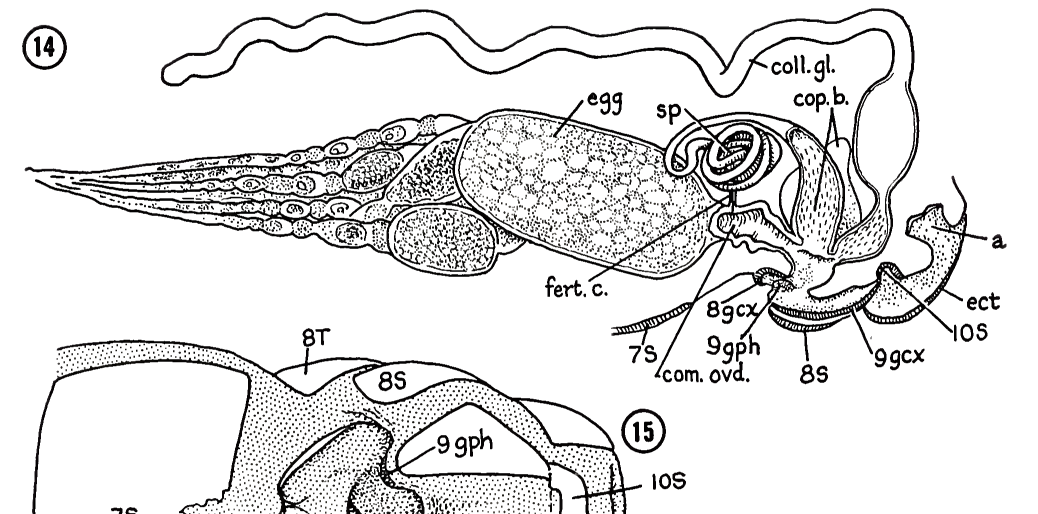

$75 \quad$ (3) (1,

(18)
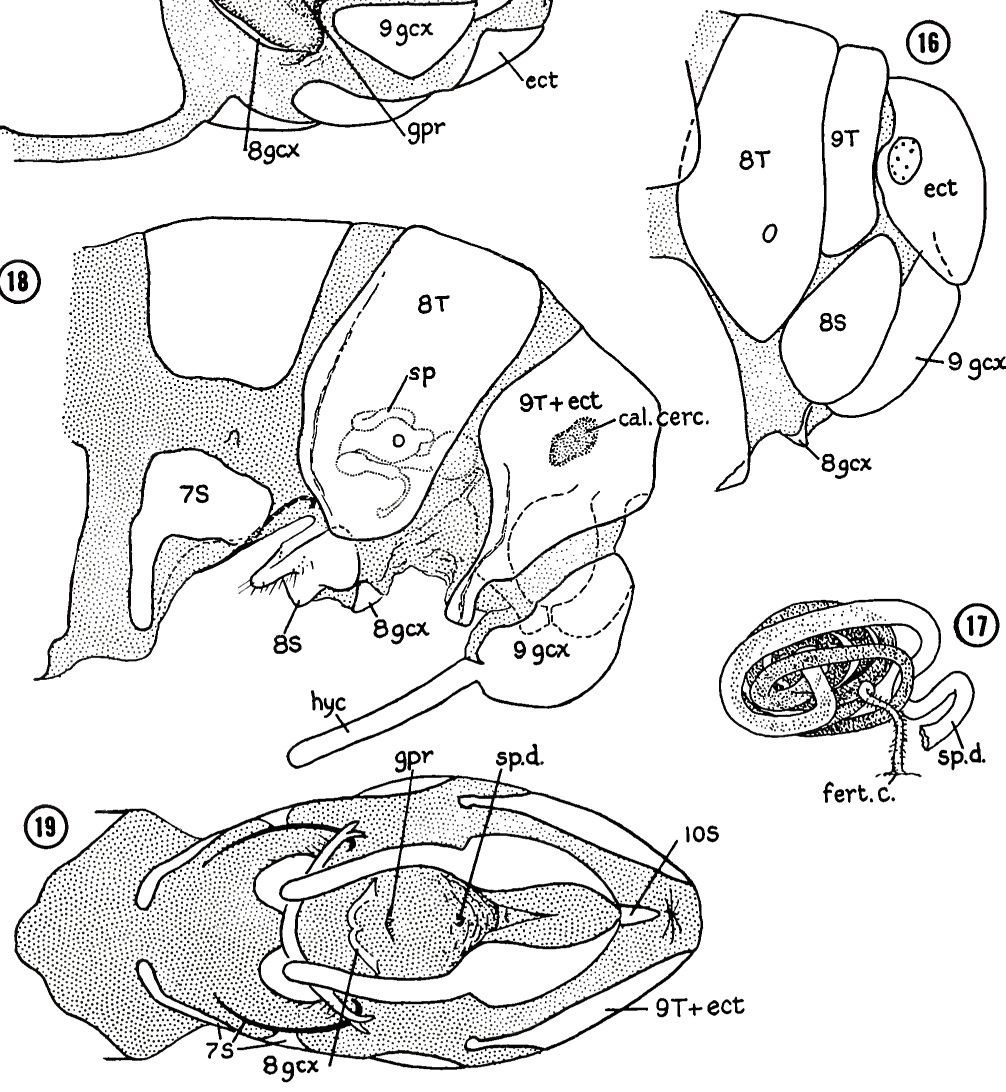

MacLeod and Adams - Berothidae 
ing so narrowed that a condition has been reached where there seems to be only a single sclerite (figs. IO, I I, gs. gcx). The presence of setae on this structure provides confirmatory evidence of its composite origin since in our experience the gonarcus rarely bears setae while the gonocoxites usually do.

The free, distal portion of the mediuncus frequently undergoes extreme elongation in different groups of berothids, producing an attenuate structure which may be further increased in length by the presence of long setae at its distal end. This elongate organ is carried, in the manner of a coiled watch spring, in a reflected internal pocket of membranous cuticle. The male of Naizema mendozina which we have illustrated (figs. 2I, 22) illustrates a moderate development in this direction. Tjeder (I954) has applied the term "penisfilum" to such specialized mediunci. At the opposite extreme, species of $L_{0}$ mamyia have the distal portion of the mediuncus reduced so that only the basal sclerite in the dorsal wall of the ejaculatory duct remains (figs. IO, II, I2, mu). In this genus a distal tuft of fine, short setae with specialized tips is present without any elongation of the mediuncus (fig. I2).

The system of homologies we have used for the external female genitalia is based upon an extensive study of neuropteran genitalia, which will be published elsewhere. A large 8th sternite, bearing setae, is readily identifiable in most Sialodea and many Planipennia.

\section{Explanation of Plate 33}

Cyrenoberotha penai n. sp.: Figs. 14-17, based on several $q$ paratypes. Lomamyia flavicornis (Walker), + : Figs. 18-19, drawn from a specimen from Washington, D. C., Rock Creek Park; 10 June 1958 (M58-25\# 10); E. MacLeod Col.; in MacLeod collection.

Fig. 14. Detail of internal genital anatomy, lateral view, showing connections of median oviduct, spermatheca, bursa copulatrix and colleterial gland. External cuticle depicted as in median longitudinal section. Fig. 15. Ventral view of terminal abdominal segments. Genital chamber, depicted as seen when 8th gonocoxites are drawn anteriorly away from 9th gonapophyses. Fig. 16. Terminal abdominal segments, lateral view. Fig. 17. Spermatheca. Fig. 18. Terminal abdominal segments, lateral view, genital chamber depicted as opened slightly by posteriad retraction of ventral process of fused 9th tergite + ectoproct from its usual articulation against posterior end of 8th sternite. Fig. 19. Same, ventral view.

Abbreviations: a - anus; cal. cerc. - callus cercus; coll. gl. - colleterial gland; com. ovd. - common oviduct; cop. b. - bursa copulatrix; ect ectoproct; egg-mature oocyte in lateral oviduct; fert. c. - fertilization canal ; $8 \mathrm{gcx}, 9 \mathrm{gcx}-8$ th, 9th gonocoxites; 9gph - 9th gonapophysis; gprgonopore: exit of median oviduct into genital chamber; $7 \mathrm{~S}, 8 \mathrm{~S}, 10 \mathrm{~S}-7$ th, 8th, 10th sternites; sp - spermatheca; sp. d. - spermathecal duct; $8 \mathrm{~T}, 9 \mathrm{~T}$ -8th, 9th tergum; $9 \mathrm{~T}+$ ect - fused 9 th tergite and ectoproct. 
Posterior to the 8th sternite, but anterior to the genital opening, a shiny, seta-less sclerite is often found which may bear two processes posteriorly (e.g., in Sialodea, Psychopsidae, Polystoechotidae). We interpret this sclerite as the fused 8th gonocoxites and the posterior processes as their gonapophyses. We have not seen 8 th gonapophyses in Berothidae. A diagrammatically archaic 9th gonapophysis occurs on the medial margin of the ninth gonocoxites in the snake-fly Agulla. In Sialodea and Planipennia, the ninth gonapophyses, if present, are represented by small, leaf-like sclerites near the anteroventral corners of the ninth gonocoxites. These appear to have been reported previously only by Principi (1949) and Adams (1967), in the Chrysopidae.

There have been few previous attempts to relate the terminal structures of the female abdomen of the Berothidae to the basic insectan plan of the external sclerites of the female copulatory structures. Carpenter (1940), unaware of the fusion of the ectoprocts with the 9th tergite, mistook the 9th gonocoxites as the "Ioth tergites". Tjeder (1954, 1959) employed a useful and consistent terminology for the structures we have termed 8th sternite, 8th gonocoxites and 9th gonocoxites, but though his equivalent terms "subgenital plate", "postgenitale" and "gonopophyses laterales" are precise enough for descriptive purposes, they do not relate these sclerites to homologous structures of other insects. His choice of the term "postgenitale" for the 8th gonocoxites is particularly inappropriate since this sclerite is morphologically anterior to most of the female "genital" structures, including the all-important landmark of the gonopore (figs. 15, 19, 8 gcx, gpr).

Except for the morphologically oriented works of Stitz (I909, 1931), Brückner (1935) and Principi (1949, 1954, 1956), none of whom have dealt with berothids, little attempt has been made to depict or interpret accurately the relational morphology of the genital chamber, bursa copulatrix and spermatheca. Taxonomists in particular have failed to appreciate that a large cuticular bursa copulatrix, opening from the genital chamber, is a consistent feature of all Planipennia, with the spermathecal duct serving as a reliable morphological landmark for its location. In addition, they have overlooked the relations of a second duct, connecting the spermatheca to the common oviduct (figs. I4, I7, fert. c.). In the species of Lomamyia which we have studied this duct almost certainly conveys the spermatozoa to their point of fertilization in the oviduct. In species of many families (such as many Chrysopidae) the bursa is only narrowly confluent 
with the genital chamber and is located quite close to the spermatheca to which it is connected by a slit-like opening in its floor. In these groups no appreciable spermathecal duct really exists (cf Principi, I949: fig. XIV; I954: fig. V). In the Berothidae (and closely similar Mantispidae) the greatly enlarged bursa is widely confluent with the genital chamber, while the spermatheca, located at a considerable distance from the bursa, is connected to it through a rather long spermathecal duct which is often tortuously looped. Tjeder ( 1954, 1959) has observed and figured this duct, but has not noted its connection with the bursa except in two cases (1959) where he has misleadingly termed it a "copulatory aperture" (fig. 323) and a "gonopore" (figs. 252, 253). Small spermathecal (accessory) glands have sometimes been recognized (cf Tjeder, 1959, fig. 242), but in several cases the structure which has borne this designation seems to be the fertilization canal connecting spermatheca and oviduct (cf Tjeder, 1959, fig. 313).

Judging from our own work with Lomamyia and the published accounts of several other genera (Tjeder, 1959), we believe that a very large spermatophore is probably characteristic of most berothids and that this circumstance probably provides the functional explanation of the wide-mouthed and voluminous structure of their bursae. In our laboratory studies, the formation and fate of these spermatophores was followed on many occasions. Mated females of Lomamyia were often observed to carry awkwardly a very large spermatophore protruding from the bursa for several days. During this time eggs, quite predictably, were never laid.

Examination and dissection of spermatophores revealed that invariably they consist of a rather soft, albuminous, outer layer which surrounds a comma-shaped central core of harder material. During the post-copulatory period when a female is carrying her spermatophore, the outer coat is the first portion to wear (or be eaten) away, leaving the exposed central core attached for a somewhat longer time. Inspection of cores from both fresh and worn spermatophores disclosed the unexpected fact that they are traversed throughout their length by a small central canal which is in perfect alignment with the opening of the spermathecal duct in the bursa. Presumably sperm travel up this canal to the spermathecal duct, but just how the precise confluence of the two ducts is achieved during copulation is not yet known. Quite probably the tip of the mediuncus or the tuft of prominent setae from the posterior margin of the mediuncus is inserted into the spermathecal duct during copulation, thus providing an axis 
about which the inner core of the spermatophore is secreted. However this remains to be verified.

On several occasions females of Lomamyia have been collected by us which carried spermatophores in various stages of disintegration, indicating that the fate of these structures in nature closely parallels what we have observed in the laboratory. Tjeder (1954, 1959) also studied field-collected females carrying fragments of spermatophores in two species of Acroberotha in which the structure and destruction of the spermatophore seems to be about the same as in Lomamyia. He did not, unfortunately, realize that the hard core was an integral part of the spermatophore and concluded that it was a permanent component of the female genital segments in the genus Acroberotha to which he applied the term "ovipilum".

When females have removed or lost the last traces of their spermatophores, the very extensive space of the confluent bursa and genital chamber is effectively closed to the outside by the close approximation of various sclerites, with members of different groups of berothids achieving this result by somewhat different mechanisms. The details of these differences have been noted in the descriptions of the subfamilies which we have given below.

\section{The classification of the berothidae}

The taxonomy of the Berothidae is still in a rather rudimentary state and the data provided in the present paper can do little more than to suggest what the principal groups and adaptive trends might be. The only world-wide treatments at the species level have been those of Krüger (1922) and Navás (1929). Both of these studies suffer from a heavy reliance on relatively minor details of the wing venation and wing shape, with the resulting generic and suprageneric classification bearing little resemblance to phylogenetic reality. In addition, with the exception of Nosybus, all of the species treated in these revisions are relatively specialized forms belonging to the Berothinae, so that little insight into the overall evolution of the family has been gained by their study.

In what is the best account of this family to date, Tjeder ( 1959) recognized three subfamilies: Rhachiberothinae, containing mantispidlike forms with raptorial forelegs; Berothinae, containing species with elongate, frequently falcate wings and hypocaudae on the 9th gonocoxites; and "Sphaeroberothinae" (i.e. Nosybinae, see below), with short, rounded wings and lacking hypocaudae. In spite of the limitations imposed on him by an inadequate literature and the availability 
of only a small number of South African species, Tjeder's divisions seem quite sound, although, as noted below, we believe that several of the genera which he referred to the "Sphaeroberothinae" (on the basis of their rounded wing tips) should be reassigned to the Berothinae. In addition it is now necessary to propose a new subfamily for the inclusion of Cyrenoberotha.

In the following section we have provided new descriptions for the four subfamilies and have listed all of the described genera. We have had representatives of all of the subfamilies and principal genera available for this study, the specific genera we have examined being marked with an asterisk in the list. Other than the synonymy of Espetera and Naizema noted above, all described genera are listed without indication of synonymy since so few of the type species have been examined by modern workers. Our views on certain obvious synonymies are set forth in the discussions following the subfamilies.

The four subfamilies of the Berothidae may be distinguished by the following key:

I. Forelegs cursorial; free stem of MA in hind wing vertical,

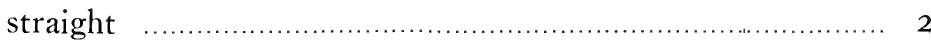

Forelegs raptorial; free stem of MA in hind wing oblique, sinuate .............................................. Rhachiberothinae

2. Ninth abdominal tergite fused with ectoprocts; face very short, not much extended ventrad of lower margin of eyes ............ 3

Ninth abdominal tergite free from ectoprocts; face conspicuously extended ventrad of lower margin of eyes .... Cyrenoberothinae

3. Bases of $\mathrm{R}$ and $\mathrm{M}$ fused in forewing, their common stem showing no trace of a composite structure, with MP diverging abruptly from $\mathrm{R}+\mathrm{MA}$ at an angle exceeding $30^{\circ} ; 8$ th sternite of female an elongate, triangular sclerite extending posteriorly beneath the fused 9th tergite and ectoprocts and the bases of the similarly produced 9th gonocoxites; hypocaudae lacking

Nosybinae

Bases of $\mathrm{R}$ and $\mathrm{M}$ in forewing usually separate, where closely adajacent or fused these bases usually preserving some trace of their separate origins and with MP diverging from $\mathrm{R}+$ MA at a more acute angle which is usually less than $20^{\circ}$; 8 th sternite of female not greatly elongate; hypocaudae present (figs. I8, 23) or absent

Berothinae

Cyrenoberothinae n. subfam.

Description. Berothids with head and mouthparts elongate; ver- 
tex lacking tubercles and elongate setae; head capsule not inflated behind eyes. Pronotum elongate, lightly constructed, not markedly deflexed laterally. Forelegs lacking raptorial modifications. 9th abdominal tergite not fused with ectoprocts, the latter with well-developed cercal calluses and trichobothrial setae.

Wings short, with rounded apices; stems of $M$ and $R$ adjacent but separate to base. Forewing with vestige of recurrent humeral vein. Hindwing lacking recurrent humeral vein; with basal free piece of MA vertical and straight; $\mathrm{CuP}$ not developed.

Male with 9th abdominal sternite well developed as an elongate subgenital plate, articulating anteriorly on the ventrally extended 9 th tergites. Gonarcus membranous in midline; gonocoxites strongly developed and well separated from gonarcus distally, articulating proximally on the latter; mediuncus with a large basal sclerite and apodeme and with a free tubular portion distally, lacking setae at its tip.

Female lacking squamae. 7th abdominal sternite well developed, slightly desclerotized in posterior midline. 8th sternite divided into two bilateral fragments, displaced posterodorsally. 9th gonocoxites lacking hypocaudae, bearing reduced remnants of 9 th gonopophyses, these latter affecting closure of genital chamber by anteriad appression against concave surface of 8 th gonocoxites. Bursa copulatrix small, widely confluent with genital chamber, with a pair of bilateral pouches. Spermathecal duct short; spermatheca a simple coiled tube, lacking enlargements and diverticula.

Type and sole included genus: ${ }^{*}$ Cyrenoberotha $n$. gen. Known only from Chile.

\section{Rhachiberothinae Tjeder, I959}

Rhachiberothinae Tjeder, 1959, South African Animal Life 6: 262.

Type genus (by original designation): Rhachiberotha Tjeder, 1959.

Description. Male unknown. Berothids with head and mouthparts short; vertex with at most a slight suggestion of tubercles whose position is marked by a few elongate setae; head capsule moderately inflated behind eyes. Pronotum elongate, lightly constructed, slightly deflexed laterally. Forelegs with raptorial modifications consisting of elongate coxae and swollen femora, with large macrotrichia, against which tibiae and tarsae can be reflexed. 9th abdominal tergite fused to ectoprocts, the latter with reduced or absent cercal calluses and trichobothrial setae. 
Wings short, with rounded apices; stems of $R$ and $M$ adjacent but separate to base, or bases of these veins fused in forewing. Recurrent humeral vein not present. Hindwing with basal free piece of MA transverse, sinuate; with base of $\mathrm{CuP}$ present, fusing with IA.

Female lacking squamae. 7 th abdominal sternum well developed. 8th sternum reduced to thin cresentic sclerite in midline, or absent. 9th gonocoxites with minute or small hypocaudae; remnants of 9th gonapophyses produced anteriad as slender bands along ventrolateral margins of genital chamber, the gonapophyses affecting the closure of the genital chamber by pressing anteriomesad against convex membranous lobe occupying the usual position of the concave 8th gonocoxites behind region of 8th sternum. Structure of bursa copulatrix unknown. Spermathecal duct elongate; spermatheca complexly coiled, with enlargements and diverticula.

Included genera: *Rhachiberotha Tjeder, 1959; Mucroberotha Tjeder, 1959. Both from Rhodesia.

Discussion. The manner of the closure of the genital chamber described above is based on our examination of specimens of the two species of Rhachiberotha and this may not be quite correct for Mucroberotha. Judging from Tjeder's figures ( 1959 : figs. $253 \mathrm{~K}-253 \mathrm{M}$ ), weakly sclerotized 8th gonocoxites ("postgenitale") seem to be present in this latter genus and the closure of the genital chamber may not differ appreciably from the manner described above for Cyrenoberotha.

\section{Nosybinae new name}

Sphaeroberothinae Krüger, 1922, Stett. Ent. Zeit. 83: 75. Nomen nudum. Sphaeroberothini Navás, 1927, Bull. Soc. R. Ent. d'Egypte 1926: 206; 1929, Mem. Acad. Cience. Zaragoza 2: 68, 106. Nomen nudum.

Sphaeroberothinae Tjeder, 1959, South African Animal Life 6: 281. Type genus (by original designation): Nosybus Navás. Nomen nudum.

Description. Berothids with head and mouthparts very short; vertex with lateral tubercles well developed and with area of median tubercle raised as a larger, convex swelling which is not distinctly tuberculate, all swellings bearing tufts of long setae; head capsule moderately inflated behind eyes. Pronotum quadrate, lightly constructed, not deflexed laterally. Forelegs without raptorial modifications. 9th abdominal tergite fused to ectoprocts, the latter lacking cercal calluses and trichobothrial setae.

Wings short, with rounded apices; recurrent humeral vein not present. Stems of $\mathrm{R}$ and $\mathrm{M}$ fused in forewing, closely adjacent but 
separte to base in hindwing. Hindwing with basal free piece of MA vertical, straight; $\mathrm{CuP}$ not developed.

Male with 9th abdominal sternite reduced, transverse. Gonarcus not desclerotized in midline; gonocoxites well developed, widely separated from gonarcus distally, articulating on the latter proximally; mediuncus greatly elongate, withdrawn into an internal pouch.

Female lacking squamae. $7^{\text {th }}$ abdominal sternite well developed. 8th sternite produced posteriad as an elongate triangular sclerite beneath fused 9th tergite + ectoprocts and the bases of the similarly produced 9th gonocoxites, the latter without hypocaudae or traces of 9th gonapophyses. Genital chamber closed by posteriad appression of 8th sternite beneath bases of gonocoxites. Bursa copulatrix small, widely confluent with genital chamber. Spermathecal duct very long; spermatheca a complexly coiled tube, with enlargements and diverticula.

Type and sole included genus: *Nosybus Navás, i9ı. Previously known from southeast and central Africa. We have seen specimens from northern Angola (Malange).

Discussion. The name of this taxon has been a continuing source of confusion, the early proposals of Krüger and Navás being nomina nuda since no included genus bore the name Sphaeroberotha. Such a genus was not even described until 1930 when Navás proposed this name for his new species Sphaeroberotha dumonti and referred to it as "Genus Sphaeroberothinorum" (p. 133) and "... de este nuevo género en la tribu de los Esferoberótinos...." (p. I35). We have examined the holotype female of this species and find that this insect is a member of the Berothinae so that if Navás' action of 1930 should be considered as a validation of a family-group name based on Sphaeroberotha, this name would fall into the synonymy of Berothinae.

Explanation of Plate 34
Naizema mendozina (Esben-Petersen), ô (lectotype), $q$ (lectoparatype) : drawn from specimens from Mendoza, Argentina; Haarup; in the collection of the Universitetets Zoologiske Museum, Copenhagen.

Fig. 20. Lateral a spect of terminalia of male. Fig. 21. Detail of terminalia of male, posterio-ventral view. Fig. 22. Detail of gonarcus, gonocoxites, mediuncus, and hypandrium internum, lateral aspect. Fig. 23. Terminal abdominal segments of female, lateral view. Fig. 24. Same as Fig. 23, ventral view. Fig. 25. Right forewing of male.

Abbreviations: a - anus; coll. gl. - collaterial gland; cop. b. - copulatory bursa; $8 \mathrm{gcx}, 9 \mathrm{gcx}-8$ th, 9th gonocoxites; 9 gph -9 th gonapophysis ; gpr - gonopore; gs - gonarcus; hy. i. - hypandrium internum; mu - mediuncus; $7 \mathrm{~S}, 8 \mathrm{~S}-7$ th, 8 th sternite; sp - spermetheca; $9 \mathrm{~T}+$ ect-fused oth tergite and ectoproct. 


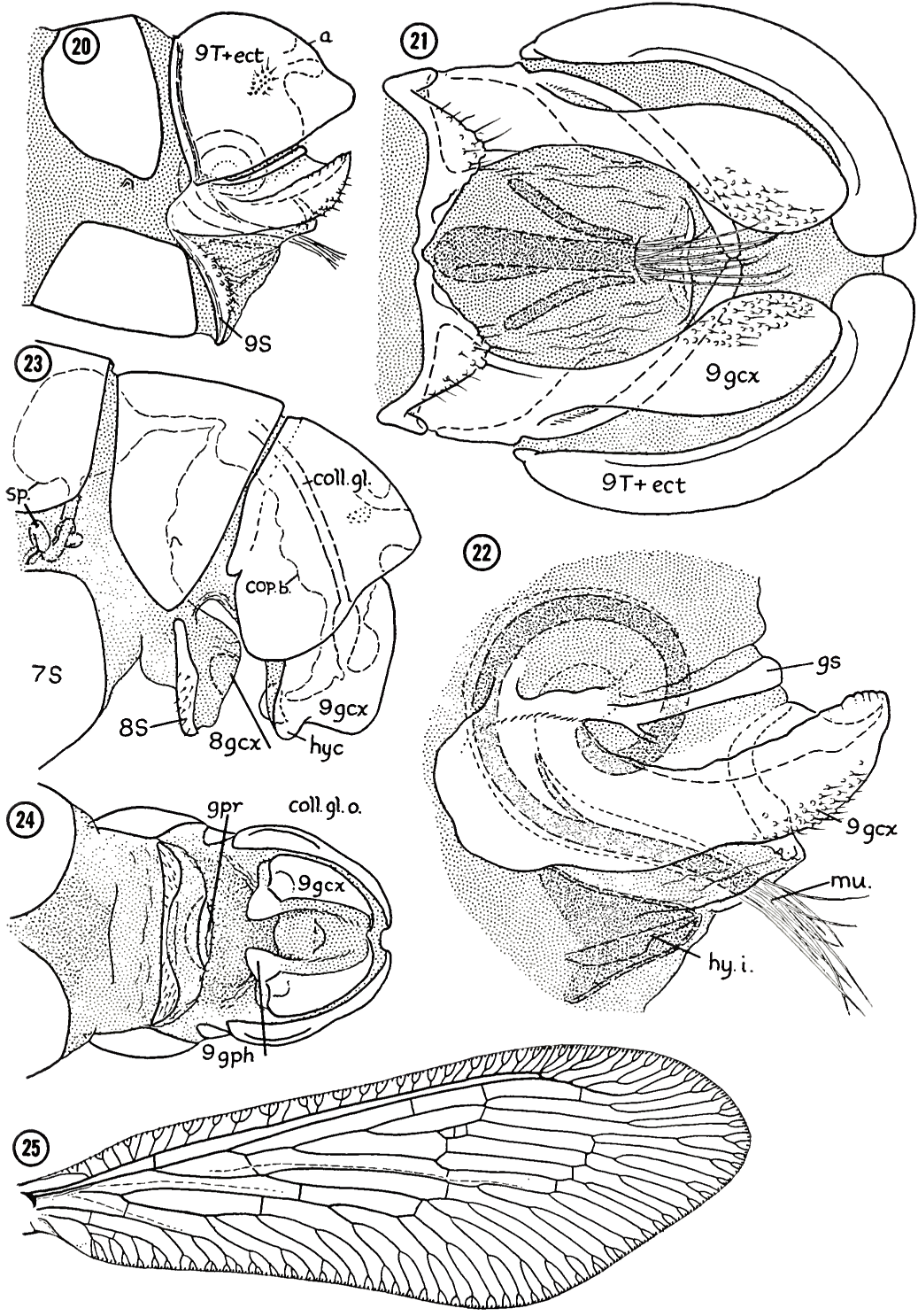

MacLeod and Adams - Berothidae 
The final attempt, by Tjeder (1959), to validate the name Sphaeroberothinae (by the designation of Nosybus as the type genus) is contrary to the Rules.

It is not possible to resurrect this name for a valid family-group taxon and it is therefore necessary to propose the new name Nosybinae for the taxon to which the name Sphaeroberothinae has previously been applied.

Krüger, Navás, Banks and Tjeder have placed the additional genera Cycloberotha, Costachillea, Sphaeroberotha, and Berothella in the same suprageneric taxon as Nosybus. The only unifying feature of this assemblage has been the short wings with rounded apices. Actually these genera show only a superficial similarity to Nosybus, the first three being rather ordinary berothines, with such typical features as well-developed hypocaudae and, in Cycloberotha and Costachillea, squamae on the wings of the females. The type species of Berothella, B. phantoma Banks, has not been available to us for study. The holotype male of the other described species of this genus, $B$. pretiosa Banks, has been examined by us. It is a dilarid, so we have provisionally excluded Berothella from the Berothidae pending a study of its type species. ${ }^{4}$

\section{Berothinae Handlirsch, I908}

Berothinae Handlirsch, 1908, Die Fosselen Insekten, p. 42. Type genus (by tautonomy): Berotha Walker, 1860. Krüger, 1922, Stett. Ent. Zeit. 88: 56. Tjeder, 1956, South African Animal Life 6: 293.

Berothini Banks, 1913, Trans. Amer. Ent. Soc. 39: 211. Navás, 1921, Ann. Soc. Sci. Bruxelles 40: 230; 1927, Bull. Soc. R. Ent. d'Egypte 1926: 206; 1929, Mem. Acad. Cienc. Zaragoza 2: 23, 105 . Handschin, 1935, Rev. Suisse Zool. 42: 700.

Esferoberótinos, Sphaeroberothinorum Navás, 1930, Broteria 26: 133-135. Type genus (by tautonomy): Sphaeroberotha Navás, 1930. NEW SYNONYMY.

Description. Berothids with head and mouthparts short to very short; vertex with lateral tubercles weakly to strongly developed, anterior tubercle usually not in evidence, vertex with elongate setae which are not necessarily confined to tubercles; head capsule moderately to strongly inflated behind eyes. Pronotum transverse, lightly constructed or elongate and of a more massive construction, always

\footnotetext{
${ }^{4}$ The holotype $\hat{\delta}$ of $B$. phantoma is now located in the British Museum. At our request, Mr. D. E. Kimmins has examined this specimen and informs us that this species also belongs to the Dilaridae, so that Berothella should definitely be removed from the Berothidae.
} 
deflexed laterally. Forelegs without raptorial modifications. 9th abdominal tergite fused to ectoprocts, the latter bearing obsolescent cercal calluses and trichobothrial setae.

Wings moderately to strongly elongate with rounded or with subfalcate or falcate apices; recurrent humeral vein present as a vestige or absent; stems of $\mathrm{R}$ and $\mathrm{M}$ closely adjacent but separate to base or fused for a short distance in forewing. Hindwing with basal free piece of MA vertical, straight; $\mathrm{CuP}$ not developed.

Male with 9th abdominal sternite reduced, transverse. Gonarcus arms fused or desclerotized in midline; gonocoxites developed and widely separated distally from gonarcus, or closely adjacent to gonarcus throughout their length; mediuncus represented as a small sclerite or elongate and withdrawn into an internal pouch, always with a tuft of setae at its tip.

Female with squamae on coxae, pleurae, or wings, or else these scales lacking. 7th abdominal sternite well developed, or slightly descelerotized in posterior midline, or showing various degrees of reduction until, at extreme, represented only as small lateral fragments. 8th sternite a small, cresentic sclerite or, more usually, a large frequently complex ventral sclerite. 9th gonocoxites occasionally lacking hypocaudae or with these structures very small, more usually with hypocaudae well developed; traces of 9th gonapophyses lacking. Genital chamber closed by anteriad appression of membranous medial surface of 9 th gonocoxites against concave sclerotized surface of 8 th gonocoxites. Bursa copulatrix large, widely confluent with genital chamber. Spermathecal duct short and membranous or, more usually, elongate and well sclerotized; spermatheca complexly coiled, with enlargements and usually with diverticula.

Discussion. The following additional family group names have been utilized for various subdivisions of the Berothinae: Trichomatidae Tillyard, I9ı6 and Trichomatini Navás, I929; Naizemini Navás, I92 I ; Spermophorellini Navás, I92 I ; Nodallini Navás, I927. These have not been placed in formal synonymy, since some of these may prove valid at the tribal level when the interrelationships of the many genera of the Berothinae have been worked out.

A total of twenty generic names have been used for berothids which belong to this subfamily. These names, with their geographic distribution indicated in parentheses, are: *Acroberotha Krüger, 1922 (southern Africa, China, Japan, southeast Asia, Australia); *Berotha Walker, I86o (Africa, Madagascar, Hindustan, India, Ceylon, Java, Formosa); Costachillea Navás, I929 (north Africa); *Cycloberotha 
Navás, I929 (Australia); Dasypteryx Stein, I863 (Greece); *Espetera Navás, 1929 [三 Naizema Navás, I919, see above] (Argentina); *Frawalkeria Navás, 1929 (Borneo, Formosa); Isocelipteron Costa, I 863 (southern Europe); Lekrugeria Navás, I929 (India) ; *Lomamyia Banks, I904 (North America, we have also seen a specimen from Zamorano, Honduras); Naizema Navás, 1919 (Argentina) ; *Nodalla Navás, 1927 (Egypt); Podallea Navás, 1936 (Ethiopia); Protobiella Tillyard, 1923 (New Zealand); Sisyrura Navás, 1905 (China); *Spermophorella Tillyard, I9I6 (Australia) ; *Sphaeroberotha Navás, I930 (Tunisia) ; *Stenobiella Tillyard, I9ı6 (Australia); *Trichoberotha Handschin, I935 (Australia); Trichoma Tillyard, I9ı6 (Australia).

Krüger (1923) has also described a species, Proberotha prisca, from the Baltic amber; unfortunately this specimen has not been located for study so that its subfamily placement cannot now be ascertained. An undescribed amber berothid in the collection of the Museum of Comparative Zoology which, judging from Krüger's rather incomplete description of $P$. prisca, is probably not congeneric, has long hypocaudae and is obviously a berothine.

The genera Dasypteryx, Frawalkeria, Isoscelipteron, Podallea, and Sisyrura are obviously very close to Berotha and several of these have long been regarded as synonyms of this genus. Lekrugeria and Acroberotha, although presumed to differ from Berotha in the number of branches of the radial sector of the forewing and shape of the apex of the wings, are also at best only poorly distinct and may prove to be synonymous with Berotha when the structure of these species becomes known in detail. An appreciation of the variability of such characters as the branching of the radial sector and the shape of the wing apex can be gained from a review of the species of the well-studied genus Lomamyia. These show considerable individual variation in the number of branches of $\mathrm{Rs}$, reaching as high as 7 (not counting MA) in some specimens of L. fulva Carpenter, and present wing shapes ranging all the way from slightly pointed (L. longicollis (Walker) ) to species with strongly falcate apices ( $L$. hamata (Walker), L. squamosa Carpenter). It seems unlikely that stable generic limits will be found utilizing such characters as these.

\section{Notes on the eVOLUtion of THE Berothidae}

The Subfamilies of the Berothidae. An estimate of the overall degree of evolutionary change from the presumed structure of ancestral berothids of eight key genera of the Berothidae is presented 
in Tables I and II. In this analysis, twenty-three morphological characters, which are judged to be of phylogenetic importance, have been coded into "primitive" and "derived" states by a study of the form of these characters in other groups of present-day Neuroptera. We have regarded as primitive states those which, because of their occurrence in generalized members of related families, are believed to reflect the state of these characters in the common ancestors of these families and, presumably, in the direct ancestors of the Berothidae as well. Derived states are presumed to have departed from the primitive states in the manner specified in Table I. In deducing the states of these characters, particular attention has been paid to their condition in the Mantispidae, Dilaridae, and Neurorthidae ${ }^{5}$, since study of both the larval and adult stages of these groups has indicated a close phylogenetic relationship of these taxa with the Berothidae (MacLeod, I964; MacLeod and Adams, unpublished).

Study of these data emphasizes the evolutionary mosaicism of each of the subfamilies and shows that although there is a preponderance of primitive states in the Cyrenoberothinae, Rhachiberothinae, and Nosybinae, important specializations are present in each of these groups which makes it unlikely that either is ancestral to the other two or to the Berothinae. Thus in the Cyrenoberothinae, the elongate head, non-tuberculate vertex, and divided 8 th abdominal sternum of the female are specializations which eliminate this taxon as a candidate for the ancestor of the other subfamilies. Likewise the specialized prothorax and prothoracic legs and the reduction of 8th abdominal sternite in the female rule the Rhachiberothinae out as direct ancestors of the Nosybinae and Berothinae, while the additional specializations of the fusion of 9th abdominal tergite and ectoprocts and the loss of the recurrent humeral vein in the forewing eliminates the Rhachiberothinae from the ancestry of the Cyrenoberothinae as well. Finally the specializations of the fusion of the stems of the radius and media in the forewings and the greatly elongate 9 th gonocoxites of the females argue that the Nosybinae could not serve as ancestors of the Rhachiberothinae or Berothinae, while the additional features of the fusion of 9th abdominal tergite and ectoprocts and the loss of the cercal callus removes them as ancestors of the Cyrenoberothinae.

This analysis also emphasizes the rather generalized nature of Naizema within the Berothinae and raises the question as to whether

\footnotetext{
${ }^{5} \mathrm{~A}$ study of the adults and presumptive larvae of this group has convinced the senior author that this group should be treated as a distinct family. The evidence justifying this conclusion will be presented in a separate publication.
} 


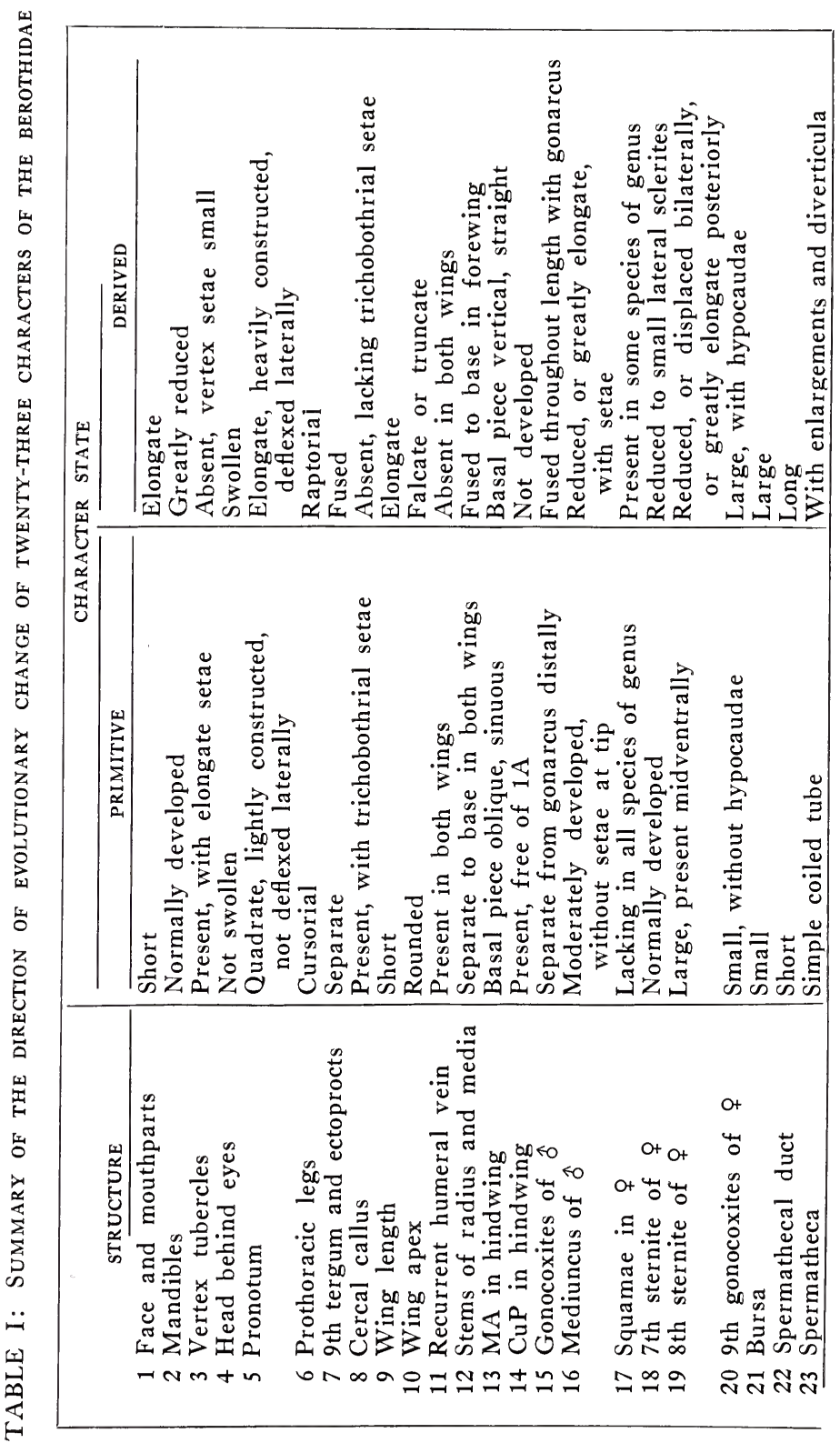




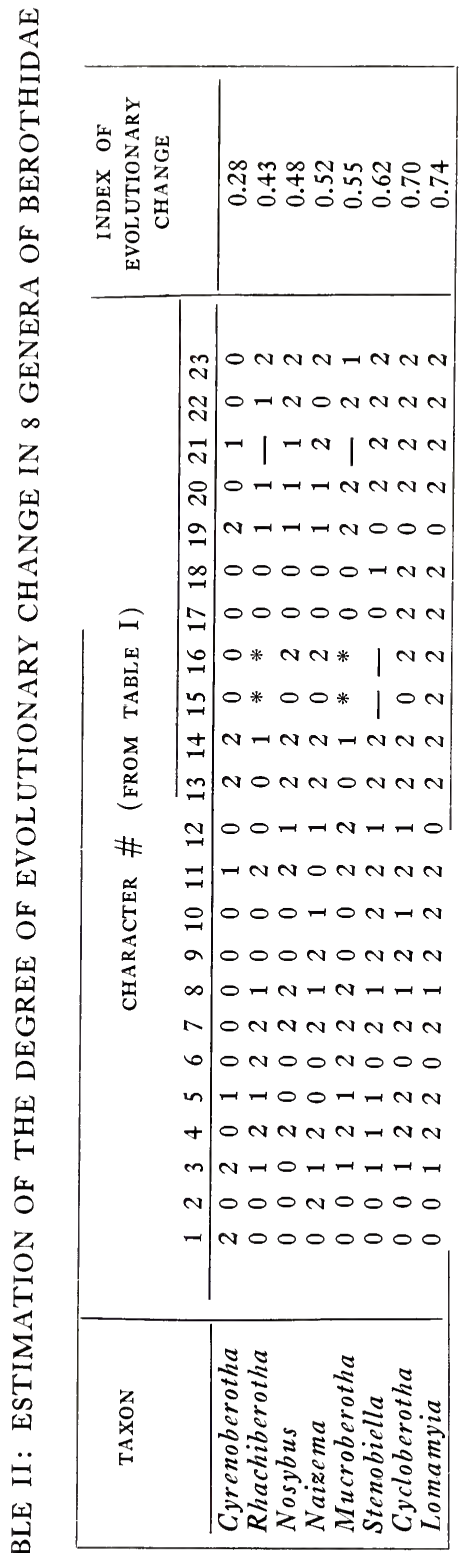

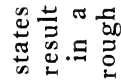
可可范

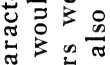



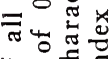
4웡. 宁导 옾 ฮี สี .乌ّ心 Еอ ड़ 플 흉

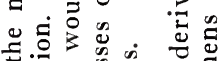

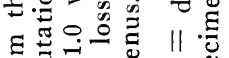

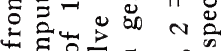

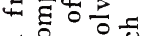
월웡

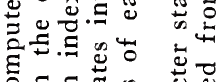

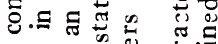


胥

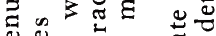

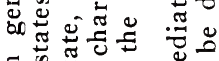
टी क

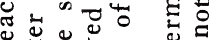

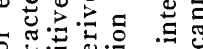
เั

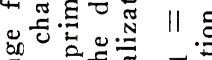
牙岁告 डै तह

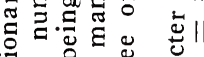



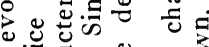

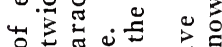

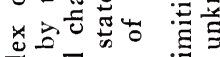



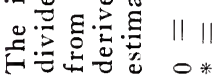


this genus is correctly referred to this subfamily. Our treatment of Naizema is based on an examination of the direction of the specializations of this group. Thus the elongation and subfalcation of the wing; elongate, coiled mediuncus with setae at its tip; incipient development of hypocaudae; and the bulb-like enlargement of a portion of the spermatheca are all specializations of a berothine type and argue that Naizema has stronger phylogenetic relationships with the other genera of the Berothinae than with any other group. The gap between Naizema and other berothines is, however, considerable and tribal distinction may well be justified when more complete knowledge of the other genera of this subfamily is available.

Relationship to the Mantispidae. On the basis of the similarities in the structure of their adults and on certain general parallels in their life histories, Tjeder ( I959) pointed out the likelihood of a close phylogenetic relationship between the Berothidae and the platymantispine Mantispidae. Some of the items on Tjeder's list of similarities ( $1959: 273$ ), such as the pectinate branching pattern of Rs in the forewing, the sinuate course of the base of MA (" $r-m$ vein") in the hindwing, the presence of trichosors, the occurrence of similarly shaped mouthparts, and the similarly shaped distal tarsomere of the anterior leg, actually prove nothing since they occur in many other, distantly related groups of Neuroptera as well. The additional similarity of the fusion of the 9th abdominal te gite with the ectoprocts, noted by Tjeder in Plega, seems more likely to be the result of parallel evolution, since these sclerites are unfu ed in Cyrenoberotha and in such generalized platymantispines as Diepanicus and Gerstaeckerella. We believe, however, that Tjeder's central thesis is certainly corrct and that it is further stiengthened by several of the structural details of Cyrenoberotha and other genealized berothids.

The form of the gonarcus and gonocoxites of uncpecialicel berothids such as Cyrenoberotha, Nosybus, Naizema, and Trichoberotha are very similar to the pattern found in all of the Mantispidae kiown to us. In these groups the well-developed gonocoxities are widely separated from the gonarcus distally, while these two sclerites form a strong articulation proximally. A strong similarity also exists between Cyrenoberotha and many mantispids in the form of the mediuncus which is separated from the gonarcus and has the form of a basal plate in the roof of the ductus ejaculatorius from which a free, posterior extension is developed. Comparisons have previously been a awn (Tjeder, I959) between the extremely elongate posterior extension 
("penisfilum") which the mediuncus undergoes in some genera of both the Berothidae and Mantispidae. Since this modification seems to occur sporadically only among the more specialized members of these families, it seems more likely that this similarity is also the result of parallel specializations from the more generalized type.

Additional close similarities occur between generalized berothids and the Mantispidae in the wide connection between the genital chamber and bursa; in the rather long, narrow spermathecal duct; and in the coiled tubular shape of the spermatheca which lacks prominent dilations. MacLeod (1964) has pointed out additional similarities between these two families on the basis of the structure of the larval head.

The very mantispid-like condition of the forelegs of the Rhachiberothinae suggests that the Mantispidae may have taken their origin directly from members of this group of berothids. However, such features of Rhachiberotha and Mucroberotha as the fusion of the 9th abdominal tergite and ectoprocts, the presence of hypocaudae, the loss of the recurrent humeral vein, and the development of the very characteristic marginal forking of $\mathrm{CuA}$ and the reduction of $\mathrm{CuP}$ in the hindwing are all specializations characteristic of the higher Berothidae. Since the great majority of Mantispidae lack these peculiarities, it seems quite likely that these specializations were also lacking in their direct ancestors and that these ancstors must be sought in some other group of berothids or near berothids.

It must be noted, however, that similar specializations occur, with a mosaic distribution, among certain genera of the Platymantispinae. Thus a partial or complete fusion of the 9th abdominal tergite and ectoprocts occurs in Plega and Trichoscelia (= Symphrasis); small tubercles, probably homologous to hypocaudae, are present in Drepanicus; and a reduction or loss of $\mathrm{CuP}$ in the hindwing is found in Drepanicus and Gerstaeckerella, while this latter genus shows the loss of the recurrent humeral vein as well. With the exception of the hypocaudae-l ke tubercles of Drepanicus, these are characters involving the fusion or loss of structures and their sporadic occurrence in the Platymanispinae is very likely the result of parallel evolution. The structu.al heterogeneity of this subfamily does, however, suggest that a similar variability may also have once been present in the Rhachiberothinae, so that the possibility cannot yet be ruled out that the primitive Mantispidae did evolve from some unknown rhachiberothine which lacked the specializations of the more advanced Berothidae noted above. 


\section{Acknow LedGements}

We would like to acknowledge the important assistance of Dr. Fred Keiser of the Naturhistorisches Museum, Basel, for the loan of cotypes of Trichoberotha ferruginea Handschin; of Dr. B $\phi$ rge Petersen of the Universitetets Zoologiske Museum, Copenhagen, for the loan of cotypes of Espetera mendozina Esben-Petersen; of Dr. S. Kelner-Pillault of the Musee National d'Histoire Natural, Paris, for the loan of the holotype of Sphaeroberotha dumonti Navás; and of Dr. Bo Tjeder of the Zoological Institute, University of Lund, for the loan of paratypes of his species Rhachiberotha signifera and R. smithersi. Dr. Guy L. Bush of the University of Texas has very kindly provided us with specimens of Cycloberotha and Trichoberotha which he collected in Australia.

ACKER, T.

\section{Literature Cited}

1960. The comparative morphology of the male terminalia of Neuroptera (Insecta). Microent. 24: 25-84.

Adams, P. A.

1967. A review of the Mesochrysopinae and Nothochrysinae (Neuroptera: Chrysopidae). Bull. Mus. Comp. Zool. 135: 215-238.

BRÜCKNER, W.

1935. Geschlechtsorgane und Eibildung des Neuropters Chrysopa vulgaris Schneid. Jenaische Zeitsch. Naturwiss. N. F. 69: 469-506.

Carpenter, F.

1940. A revision of the Nearctic Hemerobiidae, Berothidae, Sisyridae, Polystoechotidae and Dilaridae (Neuroptera). Proc. American Acad. Arts Sci. 74: 193-278.

FrILDRICH, $\mathrm{H}$.

1953. Neuroptera. In: Bronns Klassen und Ordnungen des Tierreichs. Band 5, Abt. 3, Buch XII, Teil a. Leipzig.

IIANDSCHIN, E.

1935. Indo-australische Neuropteren und Mecopteren. Rev. Suisse Zool. 42: 683-714.

KR̊̈GIR, I..

1922. Berothidae. Beiträge zu einer Monographie der NeuropterenFamilie der Berothiden. Ent. Zeit. Stettin 83: 49-88.

1923. Neuroptera succinica baltica. Ent. Zeit. Stettin 84: 68-92.

MACl.EOD, E.

1964. Comparative morphological studies on the head capsule and cervix of larval Neuroptera (Insecta). Ph.D. thesis, Harvard University. $528 \mathrm{pp}$.

Navís, I.

1927. Névroptères d'Egypt et de Palestine. 3me partie. Bull. Soc. Roy. Entom. d'Egypte 1926: 192-216. 
1929. Monografia de la familia de los Berótidos. (insectos Neurópteros). Mem. Acad. Cienc. Zaragoza 2: 1-107.

1930. Insectos del Museo de Paris (6 ${ }^{a}$ Serie). Broteria 26: 120-144. PRINCIPI, M.

1949. Contributi allo studio dei Neurotteri Italiani. VIII. Morfologia, anatomia e funzionamento degli apparati genitali nel gen. Chrysopa Leach (Chrysopa septempunctata Wesm. e C. formosa Brauer). Boll. Istit. Ent. Univ. Bologna 17: 316-362.

1954. Contributi allo studio dei Neurotteri Italiani. XI. Chrysopa viridana Schn. Boll. Istit. Ent. Univ. Bologna 20: 359-376.

1956. Contributi allo studio dei Neurotteri Italiani. XIII. Studio morfologio, etologico e sistematico di un gruppo omogeneo di specie del gen. Chrysopa Leach ( $C$. flavifrons Brauer, prasina Burm. e clathrata Schn.). Boll. Istit. Ent. Univ. Bologna 21 : 319-409.

STITZ, H.

1909. Zur Kenntnis des Genitalapparats der Neuropteren. Zool. Jahrb. (Abt. für Anat. und Ont.) 27: 377-448.

1931. Planipennia. In: Biologie der Tiere Deutschlands. Lief. 33, Teil 35: 67-304.

TJEDER, B.

1954. Genital structures and terminology in the order Neuroptera. Ent. Medd. 27: 23-40.

1959. Neuroptera-Planipennia. The lace-wings of southern Africa. 2. Family Berothidae. South African Animal Life 6: 256-314. 


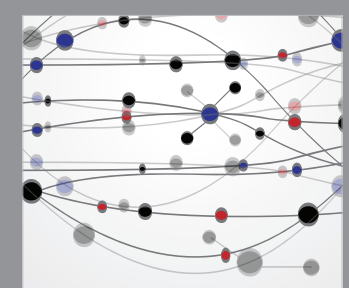

The Scientific World Journal
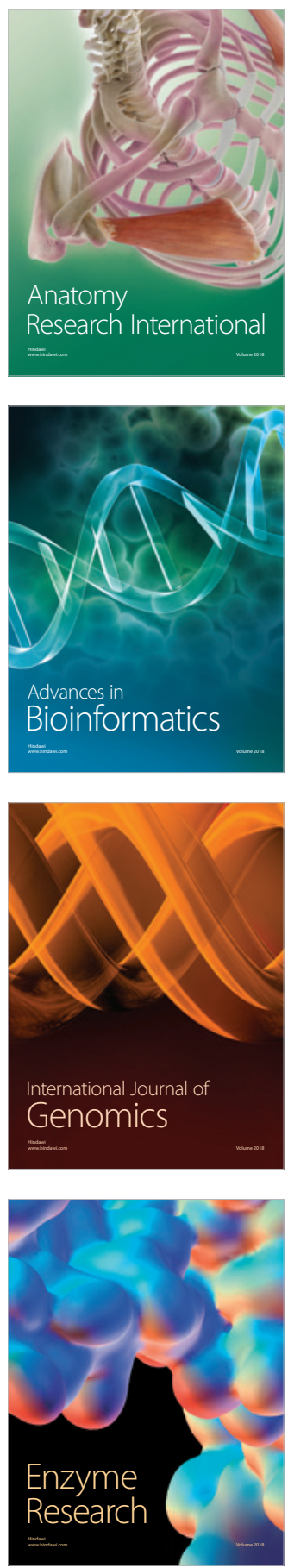
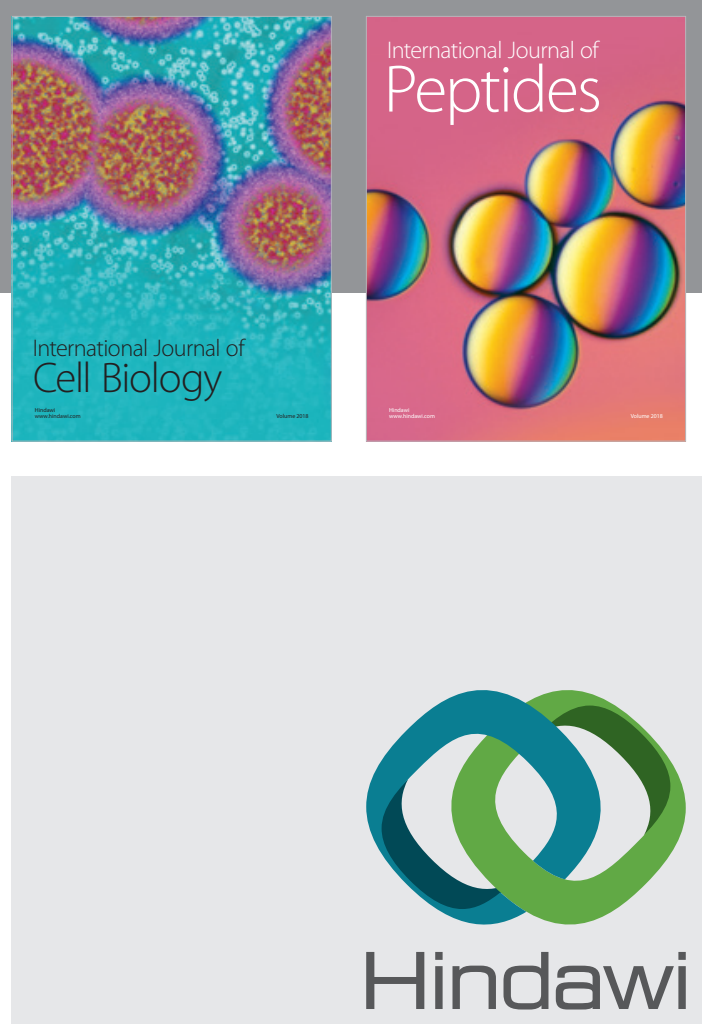

Submit your manuscripts at

www.hindawi.com
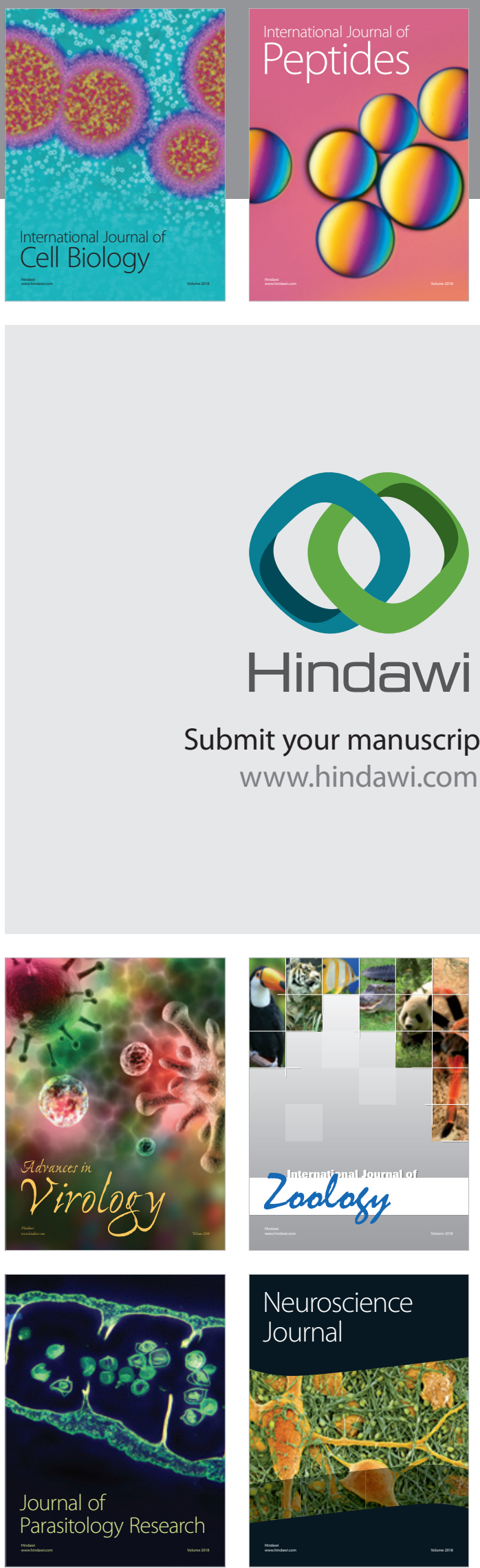
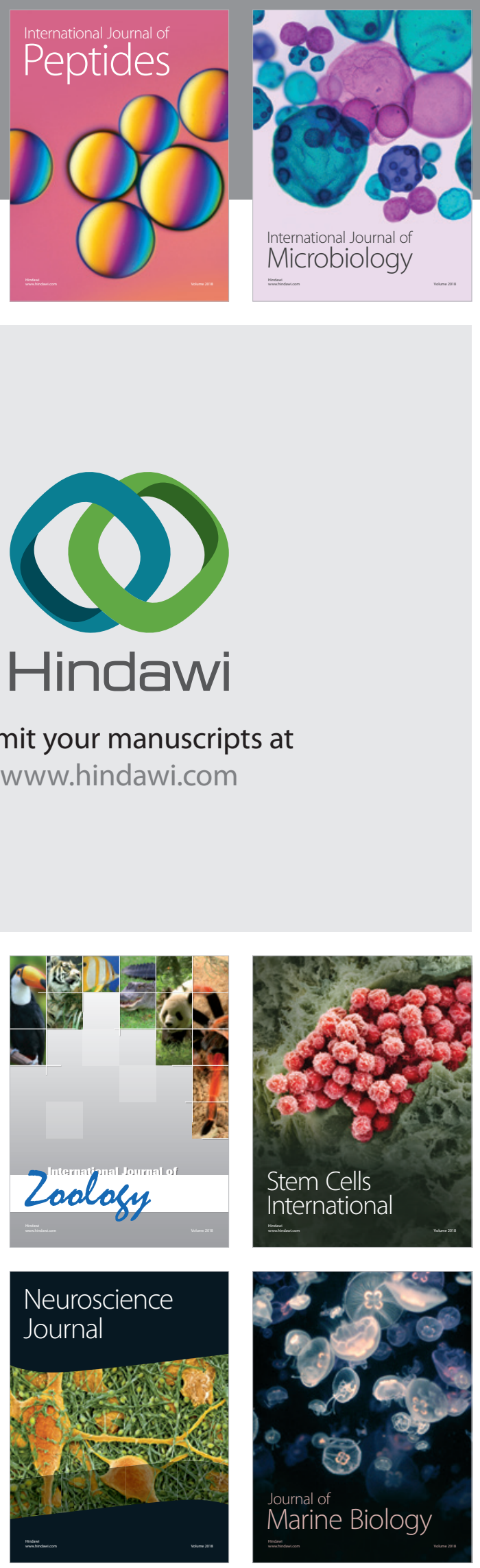
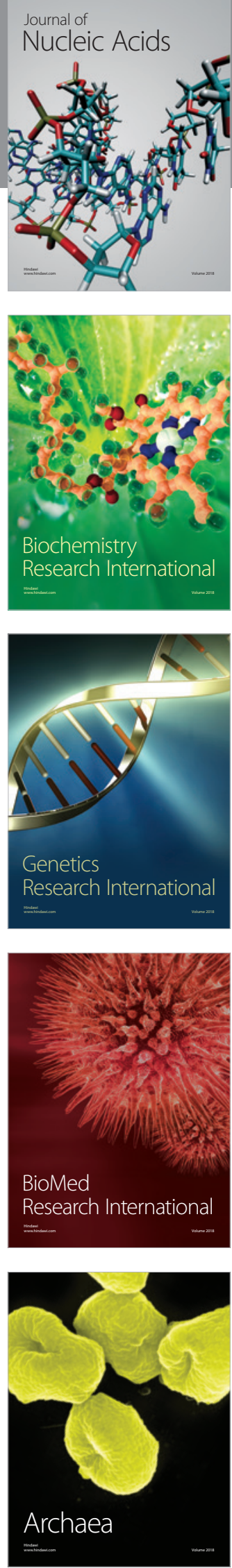